\title{
EFEKTIVITAS IKLAN BALIHO GRACE NATALIE DALAM MENINGKATKAN CITRA DIRI SEBAGAI KETUA UMUM PARTAI SOLIDARITAS INDONESIA TAHUN 2019
}

\author{
${ }^{1}$ Ayu Priana, ${ }^{2}$ Vera Wijayanti \\ ${ }^{1,2}$ Program Studi Ilmu Komunikasi Universitas Negeri Jakarta \\ ayupriana_ikom18s1@mahasiswa.unj.ac.id
}

Diterima : 06 Januari 2020; Review : 06 Februari 2020; Direvisi Author : 10 Februari 2020; Terbit : 14 Februari 2020

\begin{abstract}
ABSTRCT
Billboards are one of the media for advertising political campaigns. The concept of this research is the effectiveness of billboard advertisements. This study aims to determine the effectiveness of Grace Natalie's billboard advertisement in enhancing her self-image as Chairperson of the Indonesian Solidarity Party (PSI). This type of research is a descriptive study through a quantitative approach. The population of this study is students of the Communication Studies program at the 2018 Jakarta State University with 38 people with 35 respondents. Data collection techniques in this study were carried out by distributing questionnaires to 35 respondents. This study has one research variable, namely advertising effectiveness. Based on the results of the mean of the four dimensions tested in this study, all four dimensions have a mean value of more than 2.5. From the mean of the four dimensions, it shows that the delivery of Grace Natalie's advertisements using billboards advertising media in order to improve their self-image as Chair of the Indonesian Solidarity Party (PSI) has been effective.
\end{abstract}

Keywords: effectiveness of advertisements, political campaign advertisements, self-image.

\section{PENDAHULUAN}

Pada 17 April 2019 lalu telah berlangsung Pemilihan Presiden (Pilpres) untuk memilih presiden dan wakil presiden Indonesia periode tahun 2019-2024. Selain Pilpres, juga berlangsung Pemilihan Legislatif (Pileg) untuk memilih anggota badan legislatif negara dalam periode yang sama, yakni tahun 2019-2024. Sebelum dilaksanakan Pilpres dan Pileg, para partai politik melalakukan serangkaian kegiatan kampanye. Kampanye dilakukan tidak lain untuk memperkenalkan dan memberikan kesadarakan pada masyarakat mengenai partai politik tertentu, meningkatkan citra partai atau politisi secara perseorangan, menyampaikan visi misi partai politik, hingga berisi seruan persuasif untuk rakyat agar memilih mereka pada pemilu.

Banyak partai politik atau politisi secara perseorangan menggunakan baliho sebagai media mereka dalam menyampaikan pesan kepada masyarakat. Pemanfaatan baliho sebagai media mensosialisasikan informasi politik adalah salah satu salurn informasi yang mampu memberikan pengaruh terhadap perilaku dan sikap para calon 
pemilih di masa yang akan datang (Ali, 2013).

Salah satu politisi wanita yang menggunakan baliho sebagai media kampanye adalah Grace Natalie. Grace Natalie merupakan ketua umum Partai Solidaritas Indonesia (PSI). Grace Natalie menggunakan iklan baliho untuk meningkatkan citra diri sebagai ketua umum Partai Solidaritas Indonesia (PSI). Grace Natalie menggunakan berbagai media dalam melaksanakan kampanye politiknya. Mulai dari pemasangan iklan di televisi, melakukan promosi melalui media sosial, pemasangan iklan di youtube, hingga pemasangan iklan luar ruangan, yakni baliho. Politisi-politisi lain juga menggunakan beberapa media dalam melaksanakan kampanye politik. Mulai dari menyebarkan poster, membagikan baju-baju kepada para pendukungnya, memasang bendera partai di jalanan, memasang iklan di berbagai media seperti televisi, radio, surat kabar, majalah, media sosial, hingga pemasangan iklan luar ruangan seperti di di mobil dan baliho di jalan-jalan.

\section{Partai Solidaritas Indonesia (PSI)} merupakan salah satu partai yang bisa dibilang baru berdiri namun sudah mampu menarik perharian masyarakat. Hal tersebut dapat terjadi karena salah satunya karena mereka begitu gencar dalam mengiklankan mengenai partai mereka ke masyarakat. Oleh karena itu, peneliti melakukan penelitian mengenai iklan baliho Grace Natalie karena merasa tertarik untuk mengetahui seberapa efektif penggunaan baliho sebagai media iklan kampanye politik dalam meningkatkan citra diri Grcae Natalie sebagai ketua umum dari Partai Solidaritas Indonesia (PSI).

Baliho-baliho tersebut tentunya dibuat dengan tujuan untuk mempromosikan Grace Natalie dalam rangka kampanye pemilu 2019. Namun, seberapa efektif baliho tersebut untuk mempekenalkan Grace Natalie sebagai ketua umum Partai Solidaritas Indonesia, perlu diteliti. Oleh karena itu, peneliti tertarik untuk melakukan penelitian mengenai masalah ini. Tujuan dari penelitian ini adalah untuk mengetahui efektivitas iklan baliho Grace Natalie dalam meningkatkan citra diri sebagai ketua umum Partai Solidaritas Indonesia pada tahun 2019.

Kampanye politik merupakan kegiatan yang dimaksudkan agar mendapat dukungan, baik secara personal maupun kelompok, yang dimaksudkan di sini adalah perseorangan politisi atau sebuah kelompok partai politik. Kampanye dapat dilakukan melalui berbagai cara dan berbagai media, seperti mendatangi pemukiman warga secara langsung, melakukan kegiatan sosial, 
hingga memasang iklan. Salah satu kegiatan kampanye yang dilakukan oleh para politisi atau partai politik adalah dengan cara memasang iklan. Baik iklan tentang partai politiknya, maupun iklan yang menampilkan pribadi politisi itu sendiri. Kampanye melalui iklan dianggap lebih efektif karena iklan dapat menjangkau audiens yang lebih luas dibanding kampanye dengan cara mendatangi suatu pemukiman warga. Media yang digunakan dalam memasang iklan terdapat beberapa macam, diantaranya yakni melalui iklan elektronik, media cetak, audio, dan lain-lain.

Salah satu jenis media yang digunakan para politisi dan partai politik untuk berkampanye adalah baliho atau billboard. Baliho merupakan selembar plastik atau kain yang berukuran besar sekitar $3 \times 4$ meter, dengan format vertikal, biasanya terbuat dari bahan Vinyl $P V C$ atau stiker (Purnengsih, 2017). Baliho biasanya berada di luar ruangan, seperti tepi jalan, trotoar, jalan tol, atau di mana saja yang sekiranya banyak dilihat dan ditemui oleh orang banyak. Selain itu, karena ukurannya yang cukup besar, baliho diniliai cukup efektif sebagai media pemasangan iklan. Baliho didalamnya berupa gambar atau tulisan yang berisi informasi mengenai pesan yang ingin diiklankan.
Menurut riset yang dilakukan oleh BMI Research menyatakan bahwa tingkat konsumsi iklan masyarakat urban di Jabodetabek dalam melihat promosi luar ruangan mencapai 81\%. Angka tersebut masih dibawah iklan di televisi yang mencapai $83 \%$, namun masih di atas media online dengan $55 \%$ dan media cetak yang haya 20\% (Ratnasari, 2016). Hal ini menunjukkan bahwa baliho yang merupakan salah satu media iklan luar ruangan masih cukup efektif dibanding media iklan lainnya. Dinilai lebih bisa menjangkau masyarakat luas serta cukup efektif sebagai media iklan, banyak partai politik dan politisi menggunakan baliho atau billboard untuk memasang iklan mengenai partai mereka. Menurut Melinda (2017), terdapat sebuah kunci keberhasilan dalam memasang billboard atau baliho, yakni dengan menampilkan pesan yang dapat langsung terlihat oleh audiens, dapat dimengerti dengan mudah, dan dapat memicu motivasi dengan hanya satu pandangan ketika melihat.

Terdapat beberapa elemen yang digunakan dalam pemasangan baliho agar efektif, yakni: (a) baliho dapat mudah dilihat, (b) ditempatkan di lokasi eksklusif yang tepat sesuai dengan sasaran yang ingin dituju, (c) tidak ditempatkan terlalu berdesakan dengan iklan baliho lain, (d) 
dapat mudah dilihat dengan jelas pada siang hari dan mempunyai pencahayaan yang cukup pada malam hari, (e) ditampilkan menggunakan konsep pesan yang padat, singkat, dan cerdas, dan yang terakhir (f) memakai teknologi cetak yang bagus dan baik agar penggambaran pesan dan gambar pada baliho dapat dibaca dengan jelas (Melinda, 2017).

Pada masa kampanye politik pemilu tahun 2019, para politisi seolah berlombalomba untuk memasang iklan politik mengenai dirinya secara pribadi atau memasang iklan politik tentang partai politiknya. Karena salah satu tujuan dalam pemasangan iklan politik adalah untuk pencitraan (Chaarnaillan, Firdaus, \& Nasution, 2018). Pada iklan tersebut, mereka berusaha untuk menyampaikan tujuan politik, menonjolkan kelebihan mereka, atau sekedar memeprkenalkan diri mereka.

Pemasangan iklan politik di media massa merupakan salah satu cara yang dilakukan oleh para politisi maupun partai politik. Tidak hanya memasang iklan politik di televisi, mereka juga menggunakan media massa lain untuk memasang iklannya, salah satunya adalah pemasangan iklan di baliho.

Penelitian sebelumnya dilakukan oleh Lisa Wardi dan Dwi Kartikasari dengan judul "Analisis Efektivitas Periklanan Kek Pisang Villa Melalui Iklan Billboard dan Videotron Dengan Menggunakan Epic Model." Hasil penelitian tersebut menyatakan bahwa iklan billboard lebih efektif dibandingkan dengan periklanan melalui videotron (Wardi \& Kartikasari, 2017).

Selanjutnya, penelitian lain dilakukan oleh Sylvia Melinda dengan judul "Efektivitas Billboard dan Signboard sebagai Media Promosi Suroboyo Carnival Park". Hasil dari penlitian tersebut menyimpulkan bahwa media iklan billboard atau baliho adalah media promosi yang efektif digunakan sehingga dapat mempengaruhi responden agar pada akhirnya memutuskan untuk dating ke Suroboyo Carnival Park.

Kemudian penelitian terdahulu yang dilakukan oleh Regina Yulandari dan Zainal Abidin dengan judul "Pengaruh Iklan Politik Baliho Sebagai Bagian Dari Strategi Kampanye T. Irwan Djohan Pada Pemilu Legislatif di Kota Banda Aceh Tahun 2014". Penelitian ini memiliki salah satu kesimpulan yang menyatakan bahwa iklan politik menggunakan baliho sangat efektif dalam memberikan pengaruh kepada simpati masyarakat, melalui pesan-pesan yang membangun atau melalui visi misi, dan juga menampilkan citra diri melalui foto, 
pendidikan, partai yang menyusung para politisi tersebut. Iklan politik menggunakan baliho merupakan strategi kampanye yang andal dalam mendapatkan kemenangan. Namun itu semua kembali lagi tergantung pada bagaimana cara dan penempatan kandidat yang diiklankan (Yulandari \& Abidin, 2017).

\section{Efektivitas Iklan}

Menurut Efendy, efektivitas merupakan suatu komunikasi untuk mencapai tujuan yang telah direncanakan sesuai dengan biaya yang telah dianggarkan, jumlah anggota yang telah ditetapkan, dan waktu yang telah ditentukan (Ali, 2013). Selanjutnya Fredy Rangkuty dalam Andri (2012) menyatakan bahwa efektivitas iklan merupakan pengukuran iklan dalam arti dapat tercapainya sasaran yang telah ditentukan (Andri, 2012).

Selanjutnya menurut Rangkuti dalam Wardi \& Kartikasari (2017) menyatakan bahwa efektivitas iklan dapat dianalisis dengan AC Nielsen melalui pendekatan EPIC yang menggambarkan efektivitas periklanan dari empat dimensi, yakni:

a. Empati

Memberikan informasi apakah konsumen suka terhadap suatu iklan dan menjelaskan bagaimana konsumen melihat hubungan antara iklan dengan kepribadian konsumen, sehingga dapat memberi informasi berharga mengenai daya tarik suatu merek.

a. Persuasi

Memberikan informasi yang mampu diberikan oleh iklan untuk meningkatkan atau memberikan penguatan karakter merek tertentu, oleh karenanya pengiklan dapat memahani dampak iklan terhadap keinginan beli dan daya tarik terhadap merek tertentu.

b. Impact

Memberikan informasi apakah merek tertentu dapat terlihat menonjol jika dibandingkan dengan merek lain yang sejenis dan apakah suatu iklan dapat mengikutsertakan konsumen dalam pesan yang disampaikan.

c. Komunikasi

Menginformasikan mengenai apakah konsumen mampu ingat pesan utama yang diberikan, pemahaman konsumen dan juga kekuatan sebuah kesan yang tertinggal oleh pesan tersebut. 


\section{Baliho}

Baliho merupakan salah satu jenis media iklan luar ruangan. Menurut Ghifary (2014) billboard atau baliho merupakan ruang advertensi dalam ukuran besar yang dipancangkan di sebuah tepi jalan atau di atap sebuah gedung. Media luar ruangan merupakan iklan yang dapat menjangkau konsumen ketika sedang berada di luar rumah atau kantor. Media luar ruangan dapat merayu konsumen saat mereka sedang berada di tempat umum, ketika diperjalanan, di dalam sebuah ruang tunggu, dan juga di tempat-tempat terjadinya transaksi (Ghifary, 2014).

Salah satu cara bagaimana suatu baliho mampu menarik perhatian audiens yang melihatnya adalah dengan menampilkan gambar atau visual yang berbeda, lebih menarik, dan lebih menonjol dibandingkan dengan iklan lain yang sejenis. Apalagi, biasanya di sepanjang jalan, banyak iklaniklan sejenis yang juga bersaing dalam menarik perhatian audiens atau masyarakat yang melihatnya.

\section{Citra Diri}

Self image atau citra diri merupakan sebuah gambaran, pandangan, cerminan, dan bayangan seseorang tentang dirinya sendiri. Citra diri tersebut memiliki pengaruh yang besar terhadap cara berpikir dan tingkah lakunya dalam kehidupan sehari-hari (Rohman \& Baidun, 2013). Citra diri dapat memengaruhi bagaimana seseorang memandang dirinya sendiri dan juga bagaimana pandangan orang lain mengenai diri kita sendiri. Citra diri juga dapat berupa bagaimana seseorang ingin dilihat oleh orang lain dalam bersosialisasi dalam kehidupan sehari-hari.

Citra diri adalah bagian dari sebuah konsep diri yang memiliki keterkaitan dengan penerimaan diri, baik secara psikologis, fisik, maupun sosial. Citra diri merupakan sebuah konsepsi atau sebuah penilaian diri terhadap diri sendiri. Konsep citra diri dapat dibentuk melalui beberapa hal, dapat melalui lingkungan, keluarga, pergaulan, maupun pengalaman masa lalu (Andarwati, 2016)

\section{METODOLOGI PENELITIAN}

Jenis penelitian ini merupakan penelitian deskriptif melalui pendekatan kuantitatif. Menurut Priyono (2016: 37) penelitian deskriptif digunakan untuk memberikan sebuah penjelasan yang rinci tentang suatu fenomena. Hasil dari penelitian deskriptif biasanya merupakan tipologi atau pola tentang fenomena yang dibahas (Priyono, 2016). 
Teknik pengumpulan data pada penelitian ini dilakukan dengan menyebarkan kuesioner kepada sejumlah responden yang telah ditentukan. Populasi penelitian ini adalah mahasiswa program studi Ilmu Komunikasi Universitas Negeri Jakarta angakatan 2018 yang berjumlah 38 orang. Teknik penarikan sampel yang digunakan pada penelitian ini adalah sampel acak sederhana atau simple random sampling. Teknik acak sederhana dapat digunakan apabila melakukan penelitian dengan jumlah populasi yang homogen dan dengan jumlah polulasi yang tidak terlalu banyak (Priyono, 2016). Oleh karena jumlah populasi penelitian ini berjumlah 38 orang dan dapat dikatakan homogen, maka digunakanlah teknik acak sederhana sebagai teknik penarikan sampel pada penelitian ini.

Teknik acak sederhana merupakan salah satu jenis probability sampling. Oleh karenanya, jumlah sampel pada penelitian ini ditentukan menggunakan rumus Slovin. Rumus Slovin diperuntukkan untuk populasi yang diketahui jumlahnya, jika jumlah populasi tidak diketahui, maka rumus Slovin tidak bisa digunakan. Karena jumlah populasi penelitian ini diketahui, yakni berjumlah 38 orang, maka dapat digunakan rumus Slovin sebagai berikut:

$$
\mathrm{n}=\frac{N}{1+N e^{2}}
$$

keterangan:

$\mathrm{n}=$ jumlah sampel

$\mathrm{N}=$ jumlah populasi

$\mathrm{d}=$ nilai kritis (persentasi ketidaktelitian kerena kesalahan penarikan sampel)

$$
\begin{aligned}
& \mathrm{n}=\frac{38}{1+38(0.05)^{2}} \\
& \mathrm{n}=34,7 \text { (dibulatkan menjadi 35) }
\end{aligned}
$$

Berdasarkan hasil penghitungan menggunakan rumus Slovin tersebut, dapat diketahui bahwa jumlah sampel penelitian ini berjumlah 35 orang mahasiswa Ilmu Komunikasi Universitas Negeri Jakarta angakatan 2018.

Penelitian ini memiliki satu variabel penelitian, yaitu efektivitas iklan. Pada variabel tersebut terdapat empat dimensi yang telah dituliskan pada bagian pendahuluan di atas, yaitu dimensi empati, persuasi, impact, dan komunikasi. Dimensidimensi tersebut memiliki beberapa indikator yang dapat dilihat pada tabel operasional konsep sebagai berikut. 
Tabel 1. Operasional Konsep

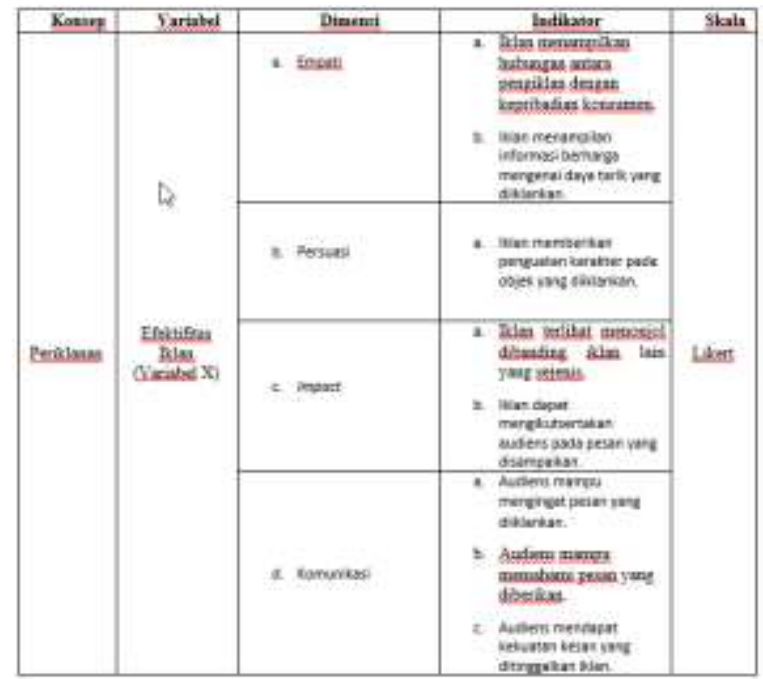

\section{HASIL DAN PEMBAHASAN}

Pengambilan data telah dilakukan oleh peneliti melalui penyebaran kuesioner kepada sejumlah sampel yang telah ditentukan sebelumnya. Penelitian dilakukan selama bulan November hingga Desember 2019. Pada kuesioner terdapat sejumlah pernyataan yang dibuat berdasarkan indikator dari dimenasi-dimensi yang terdapat pada bagian metode penelitian di atas. Berikut ini merupakan hasil jawaban per pernaytaan dari kuesioner yang telah disebar:
Tabel 2. Hubungan Iklan dengan Konsumen

$$
\mathbf{n}=\mathbf{3 5}
$$

\begin{tabular}{|l|c|c|c|}
\hline $\begin{array}{l}\text { Pernya } \\
\text { taan }\end{array}$ & $\begin{array}{l}\text { Freku } \\
\text { ensi }\end{array}$ & Persentasi & $\begin{array}{l}\text { Rata- } \\
\text { rata }\end{array}$ \\
\hline $\begin{array}{l}4= \\
\text { Sangat } \\
\text { Setuju }\end{array}$ & 3 & $8,6 \%$ & \\
\cline { 1 - 2 } $\begin{array}{l}3= \\
\text { Setuju }\end{array}$ & 15 & $42,9 \%$ & \\
\cline { 1 - 2 } $\begin{array}{l}2= \\
\text { Tidak } \\
\text { Setuju }\end{array}$ & 14 & $40 \%$ & \multirow{2}{*}{2,51} \\
\cline { 1 - 2 } $\begin{array}{l}1= \\
\text { Sangat } \\
\text { Tidak } \\
\text { Setuju }\end{array}$ & 3 & $8,6 \%$ & \\
\cline { 1 - 2 } Total & 35 & $100 \%$ & \\
\hline
\end{tabular}

Berdasarkan tabel 2 mengenai hubungan antara iklan dengan konsumen tersebut, paling banyak responden sebesar 15 orang dengan persentasi sebesar $42,9 \%$ menyatakan setuju bahwa iklan baliho Grace Natalie sebagai Ketua Umum Partai Solidaritas Indonesia (PSI) menampilkan hubungan kepribadian mereka dengan pengiklan. Kemudian sebanyak 3 responden $(8,6 \%)$ menjawab sangat setuju, 14 responden (40\%) menjawab tidak setuju, dan sisanya 3 responden $(8,6 \%)$ menjawab sangat tidak setuju. 
Tabel 3. Informasi Berharga pada Iklan

$$
\mathbf{n}=\mathbf{3 5}
$$

\begin{tabular}{|l|c|c|c|}
\hline $\begin{array}{l}\text { Pernyat } \\
\text { aan }\end{array}$ & $\begin{array}{l}\text { Frekue } \\
\text { nsi }\end{array}$ & $\begin{array}{l}\text { Persenta } \\
\text { si }\end{array}$ & $\begin{array}{l}\text { Rata- } \\
\text { rata }\end{array}$ \\
\hline $\begin{array}{l}4= \\
\text { Sangat } \\
\text { Setuju }\end{array}$ & 13 & $37,1 \%$ & \\
\cline { 1 - 2 } $\begin{array}{l}3= \\
\text { Setuju }\end{array}$ & 15 & $42,9 \%$ & \\
\cline { 1 - 2 } $\begin{array}{l}2= \\
\text { Tidak } \\
\text { Setuju }\end{array}$ & 6 & $17,1 \%$ & \multirow{2}{*}{3,14} \\
\cline { 1 - 2 } $\begin{array}{l}1= \\
\text { Sangat } \\
\text { Tidak } \\
\text { Setuju }\end{array}$ & 1 & $2,9 \%$ & \\
\cline { 1 - 2 } Total & 35 & $100 \%$ & \\
\hline
\end{tabular}

Berdasarkan tabel 3 tersebut, sebanyak 15 responden dengan nilai persentase sebesar $42,9 \%$ menyatakan setuju bahwa iklan baliho Grace Natalie sebagai ketua umum Partai Solidaritas Indonesia menampilkan informasi berharga mengenai daya tarik dari Grace Natalie. Kemudian sisanya sebanyak 13 responden $(37,1 \%)$ menjawab sangat setuju, 6 responden $(17,1 \%)$ menjawab tidak setuju, dan sisanya sebanyak 1 responden $(2,9 \%)$ menjawab sangat tidak setuju.
Tabel 4. Penguatan Karakter oleh Iklan

$$
\mathbf{n}=\mathbf{3 5}
$$

\begin{tabular}{|c|c|c|c|}
\hline $\begin{array}{l}\text { Pernyat } \\
\text { aan }\end{array}$ & $\begin{array}{l}\text { Frekuen } \\
\text { si }\end{array}$ & $\begin{array}{l}\text { Persenta } \\
\text { si }\end{array}$ & $\begin{array}{l}\text { Rata- } \\
\text { rata }\end{array}$ \\
\hline $\begin{array}{l}4= \\
\text { Sangat } \\
\text { Setuju }\end{array}$ & 10 & $28,6 \%$ & \multirow{5}{*}{3,14} \\
\hline $\begin{array}{l}3= \\
\text { Setuju }\end{array}$ & 21 & $60 \%$ & \\
\hline $\begin{array}{l}2= \\
\text { Tidak } \\
\text { Setuju }\end{array}$ & 3 & $8,6 \%$ & \\
\hline $\begin{array}{l}1= \\
\text { Sangat } \\
\text { Tidak } \\
\text { Setuju }\end{array}$ & 1 & $2,9 \%$ & \\
\hline Total & 35 & $100 \%$ & \\
\hline
\end{tabular}

Berdasarkan tabel 4 mengenai penguatan karakter oleh iklan tersebut, sebagian besar responden dengan nilai persentasi $60 \%$ menjawab setuju bahwa iklan baliho Grace Natalie memberikan penguatan karakter mengenai diri Grace Natalie sebagai ketua umum Partai Solidaritas Indonesia (PSI) pada iklan baliho yang menampilkan dirinya. Kemudian sisanya sebanyak 10 responden $(28,6 \%)$ menjawab sangat setuju, 3 responden $(8,6 \%)$ menjawab tidak setuju, dan sisanya sebanyak 1 responden $(2,9 \%)$ menjawab sangat tidak setuju. 
Tabel 5. Iklan Terlihat Lebih Menonjol Dibanding Iklan Sejenis

$$
\mathbf{n}=\mathbf{3 5}
$$

\begin{tabular}{|c|c|c|c|}
\hline Pernyataan & Frekuensi & Persentasi & $\begin{array}{l}\text { Rata- } \\
\text { rata }\end{array}$ \\
\hline $\begin{array}{l}4=\text { Sangat } \\
\text { Setuju }\end{array}$ & 9 & $25,7 \%$ & \multirow{5}{*}{3,05} \\
\hline $3=$ Setuju & 20 & $57,1 \%$ & \\
\hline $\begin{array}{l}2=\text { Tidak } \\
\text { Setuju }\end{array}$ & 5 & $14,3 \%$ & \\
\hline $\begin{array}{l}1 \text { = Sangat } \\
\text { Tidak } \\
\text { Setuju }\end{array}$ & 1 & $2,9 \%$ & \\
\hline Total & 35 & $100 \%$ & \\
\hline
\end{tabular}

Berdasarkan tabel 5 di atas, dapat diketahui bahwa sebanyak 20 responden atau senilai dengan $57,1 \%$ menjawab setuju bahwa iklan baliho Grace Natalie terlihat lebih menonjol dibandingkan iklan lain yang sejenis. Sebanyak 9 atau senilai dengan $25,7 \%$ persen responden menjawab sangat setuju dan hanya satu responden yang menjawab sangat tidak setuju atau senilai dengan 2,9\%. Dari nilai tersebut, dapat ditarik kesimpulan bahwa iklan baliho Grace Natalie sebagai Ketua Umum Partai Solidaritas Indonesia (PSI) memang terlihat lebih menonjol dibandingkan dengan iklan lainnya yang sejenis.
Tabel 6. Iklan Mengikutsertakan Audiens Pada Pesan

$\mathbf{n}=\mathbf{3 5}$

\begin{tabular}{|c|c|c|c|}
\hline Pernyataan & Frekuensi & Persentasi & $\begin{array}{l}\text { Rata- } \\
\text { rata }\end{array}$ \\
\hline $\begin{array}{l}4=\text { Sangat } \\
\text { Setuju }\end{array}$ & 3 & $8,6 \%$ & \multirow{5}{*}{2,60} \\
\hline $3=$ Setuju & 18 & $51,4 \%$ & \\
\hline $\begin{array}{l}2=\text { Tidak } \\
\text { Setuju }\end{array}$ & 12 & $34,3 \%$ & \\
\hline $\begin{array}{l}1 \text { = Sangat } \\
\text { Tidak } \\
\text { Setuju }\end{array}$ & 1 & $2,9 \%$ & \\
\hline Total & 35 & $100 \%$ & \\
\hline
\end{tabular}

Berdasarkan tabel 6 mengenai pengikutsertaan audiens pada pesan dalam iklan di atas, dapat diketahui bahwa paling banyak responden menjawab setuju dengan nilai frekuensi sebanyak 18 responden atau senilai dengan $51,4 \%$ dan sisanya sebanyak 3 orang menjawab sangat setuju, 12 orang menjawab tidak setuju, dan sebanyak 1 orang menjawab sangat tidak setuju. Hal ini berarti lebih dari setengah atau 50\% dari keseluuhan responden menjawab setuju bahwa iklan baliho Grace Natalie sebagai Ketua Umum Partai Solidaritas Indonesia (PSI) mengikutsertakan audiens pada pesan yang disampaikan iklan tersebut. 
Tabel 7. Audiens Mampu Mengingat Pesan dari Iklan

$$
\mathbf{n}=\mathbf{3 5}
$$

\begin{tabular}{|c|c|c|c|}
\hline Pernyataan & Frekuensi & Persentasi & $\begin{array}{l}\text { Rata- } \\
\text { rata }\end{array}$ \\
\hline $\begin{array}{l}4=\text { Sangat } \\
\text { Setuju }\end{array}$ & 9 & $25,7 \%$ & \multirow{5}{*}{3,11} \\
\hline $3=$ Setuju & 22 & $62,9 \%$ & \\
\hline $\begin{array}{l}2=\text { Tidak } \\
\text { Setuju }\end{array}$ & 3 & $8,6 \%$ & \\
\hline $\begin{array}{l}1 \text { = Sangat } \\
\text { Tidak } \\
\text { Setuju }\end{array}$ & 1 & $2,9 \%$ & \\
\hline Total & 35 & $100 \%$ & \\
\hline
\end{tabular}

Berdasarkan tabel 7 di atas mengenai kemampuan audiens mengingat pesan yang disampaikan oleh iklan, dapat diketahui bahwa paling banyak responden menjawab setuju dengan nilai frekuensi sebanyak 22 responden atau setara dengan $62,9 \%$ dari total keseluruhan reponden. Sisanya sebanyak 9 orang menjawab sangat setuju $(25,7 \%), 3$ orang menjawab tidak setuju $(8,6 \%)$, dan 1 orang menjawab sangat tidak setuju (2,9\%). Dari nilai tersebut, dapat diketahui bahwa sebagian besar $(62,9 \%)$ dari total keseluruhan reponden mengaku setuju bahwa mereka mampu mengingat pesan yang disampaikan oleh iklan baliho Grace
Natalie sebagai Ketua Umum Partai Solidaritas Indonesia (PSI). Dalam hal ini, berarti iklan tersebut mampu membantu Grace datalie dalam meningkatkan citra dri Grace Natalie sebagai Ketua Umum Partai Solidaritas Indonesia (PSI).

\section{Tabel 8. Audiens Mampu Memahami} Pesan yang Disampaikan

$$
\mathbf{n}=\mathbf{3 5}
$$

\begin{tabular}{|l|c|c|c|}
\hline Pernyataan & Frekuensi & Persentasi & $\begin{array}{l}\text { Rata- } \\
\text { rata }\end{array}$ \\
\cline { 1 - 3 } $\begin{array}{l}4=\text { Sangat } \\
\text { Setuju }\end{array}$ & 11 & $31,4 \%$ & \\
\cline { 1 - 3 } $3=$ Setuju & 18 & $51,4 \%$ & \\
\cline { 1 - 2 } $\begin{array}{l}\text { 2= Tidak } \\
\text { Setuju }\end{array}$ & 6 & $17,1 \%$ & \\
\cline { 1 - 2 } $\begin{array}{l}\text { 1= Sangat } \\
\text { Tidak } \\
\text { Setuju }\end{array}$ & 0 & $0 \%$ & \\
\cline { 1 - 2 } Total & 35 & $100 \%$ & \\
\hline
\end{tabular}

Berdasarkan tabel 8 mengenai kemampuan audiens dalam memahami pesan yang disampaikan oleh iklan di atas, dapat diketahui bahwa paling banyak responden menjawab setuju, dengan total 18 responden atau senilai dengam $51,4 \%$ dari total keseluruhan responden. Dengan nilai persentase yang lebih dari 50\% tersebut, berarti bahwa lebih dari setengah dari jumlah keseluruhan responden menjawab setuju 
bahwa sebagai audiens dari iklan baliho Grace Natalie dalam meningkatkan citra diri sebagai Ketua Umum Partai Solidaritas Indonesia (PSI) mampu memahami pesan yang disampaikan oleh iklan tersebut. Kemudian sisanya sebanyak 11 responden atau 31,4\% menjawab sangat setuju, 6 atau $17,1 \%$ menjawab tidak setuju, dan tidak ada yang menjawab sangat tidak setuju bahwa audiens mampu memahami pesan yang disampaikan iklan baliho Grace Natalie tersebut.

Tabel 9. Audiens Mendapat Kekuatan Kesan yang Ditinggalkan Iklan

$$
\mathbf{n}=\mathbf{3 5}
$$

\begin{tabular}{|c|c|c|c|}
\hline Pernyataan & Frekuensi & Persentasi & $\begin{array}{l}\text { Rata- } \\
\text { rata }\end{array}$ \\
\hline $\begin{array}{l}4 \text { = Sangat } \\
\text { Setuju }\end{array}$ & 12 & $34,3 \%$ & \multirow{5}{*}{3,22} \\
\hline $3=$ Setuju & 20 & $57,1 \%$ & \\
\hline $\begin{array}{l}2=\text { Tidak } \\
\text { Setuju }\end{array}$ & 2 & $5,7 \%$ & \\
\hline $\begin{array}{l}1 \text { = Sangat } \\
\text { Tidak } \\
\text { Setuju }\end{array}$ & 1 & $2,9 \%$ & \\
\hline Total & 35 & $100 \%$ & \\
\hline
\end{tabular}

Berdasarkan tabel 9 di atas, dapat diketahui sebanyak 20 responden atau senilai dengan $57,1 \%$ menjawab setuju bahwa sebagai audiens, mereka mendapat kekuatan kesan yang ditinggalkan oleh iklan baliho Grace Natalie dalam meningkatkan cirtra diri sebagai Ketua Umum Partai Solidaritas Indonesia (PSI). Kemudian sisanya sebanyak 12 responden atau senilai dengan 34,3\% menjawab sangat setuju, 2 responden atau senilai dengan 5,7\% menjawab tidak setuju, dan yang terakhir sebanyak 1 orang atau $2,9 \%$ responden menjawab sangat tidak setuju.

Tabel 10. Mean Per Dimensi

\begin{tabular}{|c|l|c|}
\hline No. & Dimensi & $\begin{array}{c}\text { Rata- } \\
\text { rata }\end{array}$ \\
\hline 1. & Empati & 2,82 \\
\hline 2. & Persuasi & 3,14 \\
\hline 3. & Impact & 2,82 \\
\hline 4. & Komunikasi & 3,15 \\
\hline
\end{tabular}

Berdasarkan tabel 10 yang berisi mean atau rata-rata per dimensi di atas, dapat diketahui bahwa dimensi yang memiliki nilai rata-rata tertinggi adalah dimensi komunikai dengan nilai rata-rata sebesar 3,15. Sedangkan nilai dimensi yang terkecil adalah dimensi empati dan impact dengan nilai masing-masing sebesar 2,82 .

Dimensi komunikasi memiliki nilai tertinggi, hal tersebut berarti bahwa dimensi komunikasi memiliki pengaruh paling besar pada efektivitas iklan baliho Grace Natalie dalam memperkenalkan dirinya sebagai Ketua Umum Partai Solidaritas Indonesia 
(PSI). Sedangkan dimensi empati dan impact memiliki nilai rata-rata terendah, dengan masing-masing nilai sebesar 2,82. Hal tersebut berarti kedua dimensi tersebut memiliki pengaruh paling kecil pada efektivitas iklan baliho Grace Natalie dalam memperkenalkan dirinya sebagai Ketua Umum Partai Solidaritas Indonesia (PSI).

Tabel 11. Mean Per Indikator

\begin{tabular}{|c|c|c|}
\hline No. & Indikator & $\begin{array}{c}\text { Rata- } \\
\text { rata }\end{array}$ \\
\hline 1. & $\begin{array}{lr}\text { Iklan menampilkan } \\
\text { hubungan antara } \\
\text { pengiklan dengan } \\
\text { konsumen }\end{array}$ & 2,51 \\
\hline 2. & $\begin{array}{lr}\text { Iklan menampilkan } \\
\text { informasi } & \text { berharga } \\
\text { mengenai } & \text { daya } \\
\text { tarik } & \text { yang } \\
\text { diiklankan } & \end{array}$ & 3,14 \\
\hline 3. & $\begin{array}{l}\text { Iklan memberikan } \\
\text { penguatan karakter } \\
\text { pada objek yang } \\
\text { diiklankan }\end{array}$ & 3,14 \\
\hline 4. & $\begin{array}{l}\text { Iklan terlihat } \\
\text { menonjol } \\
\text { disbandingkan } \\
\text { dengan iklan lain } \\
\text { yang sejenis }\end{array}$ & 3,05 \\
\hline 5. & $\begin{array}{l}\text { Iklan dapat } \\
\text { mengikutsertakan } \\
\text { audiens pada pesan } \\
\text { yang disampaikan }\end{array}$ & 2,60 \\
\hline 6. & $\begin{array}{l}\text { Audiens mampu } \\
\text { mengingat pesan } \\
\text { yang diiklankan }\end{array}$ & 3,11 \\
\hline 7. & $\begin{array}{l}\text { Audiens mampu } \\
\text { memahami pesan } \\
\text { yang diberikan oleh } \\
\text { iklan }\end{array}$ & 3,14 \\
\hline
\end{tabular}

Berdasarkan tabel mean per indikator di atas, dapat diketahui bahwa nilai mean per indikator tertinggi adalah indikator ke delapan, yakni audiens mendapat kekuatan kesan yang ditinggalkan oleh iklan dengan nilai sebesar 3,22. Sedangkan nilai mean indikator terendah adalah indikator pertama, yakni iklan menampilkan hubungan antara pengiklan dengan konsumen dengan nilai rata-rata 2,51 .

\section{PENUTUP}

\section{Kesimpulan}

Beberapa pembahasan yang telah dijabarkan di atas, kemudian dapat ditarik kesimpulan bahwa iklan baliho Grace Natalie dalam meningkatkan citra diri sebagai Ketua Umum Partai Solidaritas Indonesia (PSI) dapat dikatakan sudah efektif. Hal tersebut berdasarkan hasil jawaban responden rata-rata menjawab setuju pada beberapa dimensi efektivitas iklan yang ada pada kuesioner. Hal tersebut dapar dilihat pada tabel 10 mengenai mean atau nilai rata-rata per dimensi. Keempat dimensi memiliki nilai rata-rata lebih dari 2,5 dengan penjabaran; dimensi empati memiliki nilai rata-rata 2,82 , dimensi persuasi memiliki nilai rata-rata 3,14 , dimensi impact memiliki nilai rata-rata 2,82, dan yang terakhir dimensi komunikasi memilki nilai rata-rata sebesar 3,15. Dimensi 
komunikasi memiliki pengaruh paling tinggi sedangkan dimensi empati dan impact memiliki pengaruh paling kecil dalam mempengaruhi efektvitas iklan baliho Grace Natalie dalam meningkatkan citra diri sebagai Ketua Umum Partai Solidaritas Indonesia (PSI).

Dari hasil tersebut dapat disimpulkan bahwa penyampaian iklan Grace Natalie menggunakan media iklan baliho dalam tujuan untuk meningkatkan citra diri sebagai Ketua Umum Partai Solidaritas Indonesia (PSI) sudah efektif.

\section{Saran}

Penggunaan media baliho sebagai media iklan merupakan salah satu media yang cukup efektif. Oleh karena itu, ada baiknya penggunaan media tersebut dimaksimalkan dan dimanfaatkan dengan lebih baik lagi agar dapat digunakan sebagai media iklan dengan efektif. Khususnya pada pemanfaatan baliho sebagai media kampanye politik sesuai dengan apa yang diteliti dalam penelitian ini. Hasil temuan pada penelitian ini juga ada baiknya agar dapat digunakan untuk penelitian selanjutnya yang sejenis dan dapat dimanfaatkan sesuai kebutuhan peneliltian yang akan datang.

\section{DAFTAR PUSTAKA}

Ali, A. (2013). Efektivitas Penggunaan Baliho Pada Pemilukada (Studi pada Pemilihan Calon Walikota dan Wakil Walikota Parepare Tahun 2013). AKMEN Jurnal Ilmiah, 13(1), 1-10.

Andarwati, I. (2016). Citra Diri Ditinjau Dari Intesnsitas Penggunaan Media Jejaring Sosial Instagram Pada Siswa Kelas XI SMA N 9 Yogyakarta. EJurnal Bimbingan Dan Konseling, $3(5), 1-12$.

Andri, G. (2012). Strategi Pemasaran Dan Efektivitas Periklanan Dengan Menggunakan Metoda Komunikasi, Empati, Persuasi Dan Dampak Pada Perusahaan Pt.Bhineka Lestari Ltd. Jurnal Manajemen Dan Kewirausahaan, 3, 30-60.

Chaarnaillan, A., Firdaus, M., \& Nasution, B. (2018). Iklan Politik Baliho Dan Tayangan Iklan Politik Riau Televisi Firdaus-Ayat Terhadap Pemberian Suara Pemilih Pemula Pada Pilkada Pekanbaru 2017. Jurnal Ilmu Komunikasi, 8(4), 455-472.

Ghifary, A. (2014). Efektivitas Penggunaan Media Iklan Baliho. 2(3), 26-39.

Melinda, S. (2017). Efektivitas Billboard dan Signboard sebagai Media Promosi Suroboyo Carnival Park Pendahuluan. Jurnal E-Komunikasi, 5(1), 1-12. 
Purnengsih, I. (2017). Makna dan Pesan dalam Baliho Pemilu Legislatif 2014. Jurnal Desain, 4(03), 231. https://doi.org/10.30998/jurnaldesain.v $4 \mathrm{i} 03.1604$

Ratnasari, Y. (2016). Iklan Luar Ruangan Masih Lebih Efektif untuk Promosi.

Rohman, J., \& Baidun, A. (2013). Pengaruh Citra Diri (Self Image) dan Konformitas terhadap Perilaku Compulsive Buying pada Remaja. Tazkiya Journal of Psychology, 2(1), 281-301.

Wardi, L., \& Kartikasari, D. (2017).
Analisis Efektivitas Periklanan Kek Pisang Villa Melalui Iklan Billboard Dan Videotron Dengan Menggunakan Epic Model. Inovbiz: Jurnal Inovasi Bisnis, $\quad 5(1), \quad 67$. https://doi.org/10.35314/inovbiz.v5i1.1 73

Yulandari, R., \& Abidin, Z. (2017). Pengaruh Iklan Politik Baliho Sebagai Bagian Dari Strategi Kampanye T. Irwan Djohan Pada Pemilu Legislatif di Kota Banda Aceh Tahun 2014. Jurnal Ilmiah Mahasiswa FISIP Unsyiah, 2(3), 1-17. 